The policy measures used by the Hong Kong government to respond to the adult worker model and the male-breadwinner model

(Paper accepted by Contemporary Perspectives in Family Research for publication on 13 April 2020)

\author{
Sam Wai Kam YU ${ }^{1}$ \\ Iris Po Yee $\mathrm{LO}^{2}$ \\ Ruby Chui Man $\mathrm{CHAU}^{3}$
}

\footnotetext{
${ }^{1}$ Department of Social Work, Hong Kong Baptist University, Kowloon Tong, Hong Kong; Email: samyu@hkbu.edu.hk

${ }^{2}$ Department of Sociology, The University of Oxford, $42-43$ Park End Street, Oxford, OX1 1JD, UK; E-mail: iris.lo@ sociology.ox.ac.uk

${ }^{3}$ School of Sociology and Social Policy, The University of Nottingham, Nottingham, NG7 2RD, UK; E-mail: ruby.chau@ nottingham.ac.uk
} 


\title{
THE POLICY MEASURES USED BY THE HONG KONG GOVERNMENT TO RESPOND TO THE ADULT WORKER MODEL AND THE MALE-BREADWINNER MODEL
}

\begin{abstract}
There have been ongoing discussions on the male-breadwinner model and the adult worker model in research on family-related welfare policies. The male-breadwinner model posits that men work full-time outside the home and women take on domestic work. The adult worker model suggests that women and men should be equally expected to play an active role in the paid labor market. The aim of this article is to explore the responses made by the Hong Kong government to these two models. We meet this aim by presenting two analytical tasks. First, we study the policy measures used by the Hong Kong government to support women in their participation in formal employment and the local work-based pension scheme (the Mandatory Provident Fund) as well as other policy measures that offer potential for enabling family care providers to accumulate resources for secure retirement. Second, we discuss the findings of our study on Hong Kong young women by focusing on their views on the extent to which the government supports them to save pension incomes through the Mandatory Provident Fund and exploring alternative ways for them to achieve secure retirement. Based on these two analytical tasks, we argue that the Hong Kong government uses a 'weak action strategy' to respond to the adult worker model and the malebreadwinner model, and that this strategy fails to meet women's diverse preferences for their roles in the labor market and the family.
\end{abstract}

\section{KEYWORDS}

family; care work; labour market; policy; welfare; male-breadwinner model; adult worker model

\section{INTRODUCTION}

This article is concerned with the responses of the Hong Kong government to the malebreadwinner model and the adult worker model. The male-breadwinner model is based on the ideology of gender role divisions between men and women, with men working full-time outside the home and women responsible for domestic activities (Kovacs, 2013; Trappe et al., 2015). Moreover, women are expected to rely financially on their husbands' incomes (Ciccia \& Bleijenbergh, 2014; Crompton, 1999). The adult worker model is built on the assumption that all adults (men and women) take part in formal employment in order to secure an independent economic existence (Dyer et al., 2011) (note 1). It is supported by the view that both women and men should be respected as individuals who are capable of making their own choices in everyday life (Lewis \& Giullari, 2005). Both the adult worker model and the male-breadwinner model are seen to play an important role in shaping the development of welfare measures especially for women in Western societies (Annesley, 2007; Lewis, 2001). In the past, policymakers took the traditional gender role divisions between men and women for granted and consequently endorsed the male-breadwinner model in policymaking based on the assumption that women were obliged 
to provide unpaid care in the family (Lewis, 2001; Daly, 2011). Due to considerable social and demographic changes in Western societies over the past two decades, including a decline in fertility rates and marriage rates and a growing demand for flexible labor force, it is commonly believed that the adult worker model becomes increasingly important in guiding the formulation of policy measures as a substitute for the male-breadwinner model (Daly, 2011; Yu et al., 2019). As a result, there is a rising interest in the search for ways to put the adult worker model into practice (Yu et al., 2017). As shown in the later part of this article, there have been discussions on the relative desirability of different approaches to the adult worker model based on the experiences of the United States and Sweden in Western welfare literature (Lewis \& Giullari, 2005).

Studies suggest that some East Asian welfare regimes, such as Hong Kong, Singapore, and Taiwan, are under heavy influence of the Confucian principles (Jones, 1993; Karim et al., 2010; Leung \& Chan, 2012). Some of these principles (such as 'Three Types of Obedience and Four Virtues') are closely associated with the male-breadwinner model (note 2). However, East Asian countries also face social and demographic changes which challenge the male-breadwinner model in favor of the adult worker model. In Taiwan, there were 2.5 million households with women as economic household heads in 2016, which account for 30\% of all households and mark a significant increase of 827,000 households when compared with the figures 10 years ago (National Statistics, 2018). Moreover, women's marriage rates continue to drop in Taiwan. In 2016, only $49.9 \%$ of women aged 15 or above were married (National Statistics, 2018). In Hong Kong, more than half of local women take part in the work economy (Legislative Council Secretariat, 2019). In Singapore, the total fertility rate decreased from 3.03 to 1.42 in the period 1970 to 2001 (Teo \& Yeoh, 1999; Wong \& Yeoh, 2003).

Against this backdrop, it is worth exploring how East Asian governments respond to the malebreadwinner model and the adult worker model in the context of recent social and demographic changes. However, there is a lack of research on this issue. In response to the literature gap, this article presents two main analytical tasks. Firstly, we discuss the strategies used by the Hong Kong government to respond to the adult worker model and the male-breadwinner model. Secondly, we explore the views of women on the desirability of the strategies used by the government, especially the extent to which these strategies can enhance their freedom to choose to take part in formal employment or participate in the family as the main care provider. To illustrate our arguments, we discuss the policy measures used by the Hong Kong government to encourage women to take part in formal employment so that they can accumulate pension incomes through the Mandatory Provident Fund (henceforth MPF) and other policy measures used by the government to increase family care providers' chance of achieving secure retirement.

The MPF is a defined contribution scheme that is employment-based, privately managed, and mandatory (Yeh et al., 2018). It is one of the most important retirement protection schemes in Hong Kong (Commission on Poverty, 2015). In 2018, more than 70\% of the working population in Hong Kong was covered by the MPF. As demonstrated in this article, the policy measures that the government has adopted to support women to save pension incomes through the MPF reflect its approach to the adult worker model, whereas the policy measures employed by the government to enhance the family care providers' chance of having secure retirement reflect its approach to the male-breadwinner model. The discussion of women's discontents with these two types of government measures provides insight into the inadequacy of the government's approach to the 
two models in meeting women's diverse preferences on the ways of participating in the paid labor market as workers and in the family as care providers.

This article is organized into three parts. The first section discusses our framework for identifying different responses of the government to the male-breadwinner model and the adult worker model. The second section focuses on the government policy measures for assisting women to take part in the MPF and other policy measures which have the potential for increasing family care providers' chance of having secure retirement. By discussing these policy measures, we argue that the Hong Kong government uses a weak action strategy in its endorsement of both the adult worker model and the male-breadwinner model. The third section presents the findings of a small-scale study on the views of Hong Kong young women on the extent to which the government supports them to save pension incomes through the MPF, thereby exploring alternative ways for women to achieve secure retirement.

\section{THE FRAMEWORK}

The framework for analyzing the strategies used by the government to support the adult worker model and the breadwinner model is shown in Table 1. It is composed of nine different combinations of the government's responses to these two models. These responses can be made through the implementation of policy measures designed to assist people to participate in formal employment and/or to take part in the family as a care provider (see Table 2). It is important to note that the actual form of the adult worker model and that of the male breadwinner model manifested in people's daily lives are significantly shaped by these policy measures. The elements of the framework (the different combinations of the government's responses to the two models) shown in Table 1 are indebted to the ideas drawn from current discussions on the ways Sweden and the United States respond to the adult worker model.

Table 1 Different combinations of the strategies used by the government to respond to the adult worker model and the male-breadwinner model

\begin{tabular}{|l|l|l|}
\hline Government responses & Adult worker model & Male-breadwinner model \\
\hline Combination 1: & Strong action strategy + & Strong action strategy \\
\hline Combination 2: & Weak action strategy + & Weak action strategy \\
\hline Combination 3: & Inaction strategy + & Inaction strategy \\
\hline Combination 4: & Strong action strategy + & Weak action strategy \\
\hline Combination 5: & Strong action strategy + & Inaction strategy \\
\hline Combination 6: & Weak action strategy + & Strong action strategy \\
\hline Combination 7: & Weak action strategy + & Inaction strategy \\
\hline Combination 8: & Inaction strategy + & Strong action strategy \\
\hline Combination 9: & Inaction strategy + & Weak action strategy \\
\hline
\end{tabular}


Table 2 Policy measures for supporting the strategies used by the government to strengthen the two models

\begin{tabular}{|c|c|c|}
\hline & Adult worker model & Male-breadwinner model \\
\hline Inaction strategy & $\begin{array}{l}\text { The government stresses that } \\
\text { women should take part in } \\
\text { formal employment but does } \\
\text { not give women any concrete } \\
\text { support. }\end{array}$ & $\begin{array}{l}\text { The government stresses that } \\
\text { women should play the role of } \\
\text { the main care provider in the } \\
\text { family but does not give } \\
\text { women any concrete support. }\end{array}$ \\
\hline Strong action strategy & $\begin{array}{l}\text { Generous provision of paid } \\
\text { maternity leave benefits, } \\
\text { paternity leave benefits, and } \\
\text { parental leave benefits; } \\
\text { generous provision of } \\
\text { subsidized public care services } \\
\text { for young children. }\end{array}$ & $\begin{array}{l}\text { Generous provision of survivor } \\
\text { pension benefits, carers' } \\
\text { allowances, and spouse tax } \\
\text { allowances. }\end{array}$ \\
\hline Weak action strategy & $\begin{array}{l}\text { The government stresses that } \\
\text { women should participate in } \\
\text { formal employment. However, } \\
\text { it makes much less } \\
\text { commitment to the provision of } \\
\text { leave benefits and public care } \\
\text { services for young children } \\
\text { than those governments which } \\
\text { implement the strong action } \\
\text { strategy. }\end{array}$ & $\begin{array}{l}\text { The government stresses that } \\
\text { women should play the role of } \\
\text { the main care provider in the } \\
\text { family. However, it makes } \\
\text { much less commitment to the } \\
\text { provision of survivor pension } \\
\text { benefits, carers' allowances, } \\
\text { and spouse tax allowances than } \\
\text { those governments which } \\
\text { implement the strong action } \\
\text { strategy. }\end{array}$ \\
\hline
\end{tabular}

Governments may differ from each other in the kinds of strategy that they use to uphold the adult worker model. To illustrate this point, analysts cited the examples provided by Sweden and the United States (Annesley, 2007; Lewis \& Giullari, 2005). Both countries are seen as adult worker model welfare regimes (Annesley, 2007). Sweden is regarded as a stronger supporter of the adult worker model (Lewis \& Giullari, 2005). The Swedish government actively enhances women's opportunities for taking part in the work economy through comprehensive provision of policy measures that help reconcile work and caring duties (such as public childcare services and paid leave benefits). In contrast, the United States is commonly seen as an unsupported adult worker model welfare regime. The US government emphasizes the importance of encouraging women's labor force participation through non-interventionist policies. Its non-interventionist approach is premised on the assumption that women have no choice but to take part in the work economy in order to earn a reasonable standard of living given a lack of support from the government (Lewis \& Giullari, 2005).

With reference to the examples provided by Sweden and the United States, this article identifies three possible strategies that the government may use to respond to the adult worker model - the 
'inaction', the 'strong action', and the 'weak action'. The idea of the 'inaction strategy' draws from the way the US government upholds the adult worker model. This strategy implies that the government takes women's participation in formal employment for granted without offering women any concrete support. The idea of the 'strong action strategy' draws from the way the Swedish government strengthens the adult worker model. In implementing this strategy, the government plays a significant role in helping the family to outsource its care responsibilities to other sectors. As a result, women (and men) who take up most of the unpaid work in the family can spend more time developing their career. Implementing the 'weak action strategy' means that the government provides some support to women who want to take part in formal employment but the support is far from adequate. It is not unusual to see that some women want to participate in formal employment but fail to do so because they need to take up most of the unpaid work in the family (Bambra, 2007). If the government insists on using the inaction strategy or the weak action strategy to support the adult worker model, there is no guarantee that it can fulfil the needs of these women.

Following the way of categorizing the government's responses to the adult worker model, this article suggests three strategies that the government may use to respond to the male-breadwinner model: the 'inaction', the 'strong action', and the 'weak action'. By implementing the 'inaction strategy', the government assumes that people organize their lives with reference to the malebreadwinner model without providing any support to them. By carrying out the 'strong action strategy', the government generously subsidizes the family to encourage women to play the role of the full-time care provider in the family. This may be done through the provision of carers' allowances, survivors' pension schemes, and spouse tax allowances. The implementation of the 'weak action strategy' means that the government provides some but inadequate support to women who provide care for the family. Some women may want to play the role of the full-time provider of family care but fail to do so because their male family members lack sufficient resources to financially support their lives. The chance of meeting the needs of these women can be increased if the government adopts the strong action strategy to uphold the male-breadwinner model.

It is important to note that the strategies adopted by the government to respond to the adult worker model and the male-breadwinner model may not necessarily be favored by women. For example, a government may choose to use a weak action strategy to support the adult worker model. However, it is possible that some women are in favor of the adult worker model supported by the government's strong action strategy, whereas other women may prefer the male-breadwinner model. Hence, it is important to examine the desirability of the ways the government responds to these two models from both supply-side and demand-side angles. The supply-side angle is concerned with the above-mentioned options chosen by the government, whereas the demand-side angle is concerned with women's views on the options chosen by the government and their alternatives.

\section{MPF AND ALTERNATIVES}

In 1997, Hong Kong was reintegrated into the People's Republic of China as a Special Administrative Region. The Hong Kong government has been demonstrating its commitment to encouraging more women to participate in the workforce. For instance, in 2014, it introduced a new 'poverty alleviation policy' to encourage young people and adults, including women, to 
improve their lives through employment (Leung, 2014). In the same year, it called for public suggestions concerning how to increase women's labor force participation (HKSAR Government, 2014). The Chief Executive, in her 2017 Policy Address We Connect for Hope and Happiness, stressed the importance of protecting the well-being of women and unleashing their working potential (Lam, 2017). This reflects the government's expectation that adult women should participate in formal employment. Such an expectation can also be considered the premise upon which the MPF is based. As the MPF is one of the most important retirement protection measures in Hong Kong, almost all full-time employees aged 18 to 65 and their employers are required to contribute $5 \%$ of the employees' incomes to a recognized private provident fund each month (Shi $\&$ Mok, 2012). The main organizations that manage MPF are government approved trustees from private companies (Commission on Poverty, 2015). The participants are entitled to claim back the accumulated savings from the MPF in a lump sum at the age of 65 (note 3). According to the Commission on Poverty (2015), an individual can secure enough money for retirement through the MPF on three conditions - that he/she has earned median incomes for 40 years; that he/she has contributed to the MPF from the age of 25 to that of 65 ; and that he/she, at the age of 65 , begin to receive the non-means-tested Old Age Allowance, as a supplement to the MPF savings (note 4). By highlighting these three conditions, the Commission on Poverty conveys a message that women should play the role of the adult worker for forty years. By doing so, they can have a chance of enjoying retirement with sufficient financial resources. As mentioned in the previous section, governments may use different strategies to respond to the adult worker model. Evidence discussed below suggests that the Hong Kong government uses the 'weak action strategy' to encourage women to participate in the MPF and to strengthen the adult worker model.

Research has shown that women's responsibilities for taking care of their children make it difficult for them to develop their career and save pension incomes through earning-related pension measures (Price, 2007). There is also evidence that countries which provide more policy measures (such as formal childcare services and leave policies) to support childcare have a narrower pension gap (Foster, 2010). In other words, if the government is unwilling to devote sufficient resources to support for childcare, it is far from endorsing the strong action strategy for strengthening the adult worker model. This is the case of the Hong Kong government. Its unwillingness to give sufficient support to childcare is mainly shown in the under-development of leave benefits and formal childcare services.

In Hong Kong, there are only 5 days of statutory paid paternity leave and there is no statutory parental leave. The government has only recently planned to increase the length of statutory paid maternity leave from the current 10 weeks to 14 weeks (Xia \& Ma, 2019). There is, however, a wide gap between the end of the paid maternity leave and the age of children attending the kindergartens: 2 years and 38 weeks (note 5). Worse still, there is a lack of sufficient childcare services for addressing this gap. There is only one place of childcare centre for every 61 children aged under 2 (The University of Hong Kong, 2018). Furthermore, the fees for childcare services are unaffordable for many grass-roots families as the government subsidizes only one-fifth of the operating costs of centred-based services (Labor and Welfare Bureau, 2019). In 2018, the median monthly salaries for working mothers in the bottom half of the income distribution were below HK\$ 10,500 (note 6). However, the median monthly fees for the centre-based services were HK\$5,537 for children aged under two (Labor and Welfare Bureau, 2019; Legislative Council Secretariat, 2019). As a result, women who cannot afford to use formal childcare services or seek 
other ways to purchase care such as hiring domestic helpers have more difficulties in continuing their career after having a child. It is true that women can receive support for job-seeking from the Labor Department and the Employees Retraining Board and join their training programmes (note 7). However, the effectiveness of the government measures in improving women's position in the labor market should not be over-estimated. Most of these measures focus mainly on preparing women to take up low-paid and temporary jobs (Yu et al., 2014). Therefore, even if women receive the government's support for returning to the job market after childbirth, it is still difficult for them to earn a decent living. This, to a certain extent, explains why a wage gap between men and women persists - for example, the average monthly salaries of male and female service workers were HK\$ 14,911 and HK\$ 12,227 respectively in 2019 (Census \& Statistics Department, 2019a).

Statistics show that women have less chance than men to save sufficient pension incomes for retirement through the MPF in Hong Kong. Apart from suffering from the gender wage gap, women spend more time on doing household chores. In 2013, men's median share of the housework was 10\% whereas women's median share of the housework was $50 \%$ (Census and Statistics Department, 2015). Moreover, fewer women take part in formal employment than men. In 2018, the labor force participation rate of women stood at just 50.8\% and it was lower than that of men (68.5\%) (Census and Statistics Department, 2019b) (note 8). This difference is largely attributable to women's continued struggles to reconcile paid work with unpaid care work and inadequate childcare services (Leung, 2018; Leung \& Chan, 2012). In particular, in the wake of childbirth, mothers from low-income families are likely to encounter greater difficulties in staying in the labor market compared with those from families with higher incomes due to a lack of resources and childcare support (Leung, 2018). Furthermore, research has shown that despite a steady increase in female labor force participation among married women in Hong Kong in the past two decades, education plays a key role in this phenomenon, with higher education levels associated with a higher chance of labor force participation among women (Tong \& Chiu, 2017) (note 9). In other words, the influence of childcare responsibilities has become smaller for highly educated women who tend to seek alternatives for childcare through the private market and thus re-enter the labor market after childbirth (Tong \& Chiu, 2017), but it remains difficult for women with lower education levels to get a reasonable paid job and make sufficient contribution to the MPF after a career break. In short, in view of the under-development of childcare services and leave benefits in Hong Kong, it is reasonable to argue that the action strategy used by the government in its endorsement of the adult worker model and support for women's participation in formal employment is far from strong.

Concerning the Hong Kong government's response to the male-breadwinner model, it is noteworthy that its endorsement of Chinese tradition plays a key role in its employment of profamily policy measures which favors the model. In Chinese societies, the family has been considered the main source of welfare provision, in which women bear most of the care responsibilities (Leung, 2018). Nowadays the Hong Kong government also openly emphasizes the role of the family in meeting people's welfare needs. In an important welfare policy document Long-Term Social Welfare Planning in Hong Kong, the Social Welfare Advisory Committee (2010, p. 23) stressed that 'family is a fundamental social institution that provides essential nurture and support for individuals' and that 'better family relationships mean fewer social problems.' Taking the family-oriented culture into account, the Committee suggests that the government should build the capacity of the family to help each other instead of providing services to replace the functions 
of the family. To further strengthen the family as the main provider of welfare, the government requires people who apply for the use of important welfare measures, such as public housing and the Comprehensive Social Security Assistance (CSSA) Scheme, to go through family-based means-tests. The Commission on Poverty (2015, p.18) provided an explanation for this requirement: 'Means tests are conducted on a household basis, which is keeping with the concept of promoting mutual support among family members'. Meanwhile, it is important to note that attaching importance to Chinese traditional values is not the only reason why the government uses the means-tests to screen out applicants of social welfare. Attention should also be paid to the welfare ideologies that the government favors and the policies adopted by the Beijing government in Hong Kong. The Hong Kong government has long identified itself as a defender of capitalism (Yu et al., 2019). It associates its rule with pro-market welfare ideologies supported by liberal welfare regimes such as the UK and the US (Walker \& Wong, 2005). Moreover, it prevents the development of social welfare from undermining the interests of capitalists by prioritizing low tax and surplus budget policies (Yu \& Chau, 2019). No social welfare proposal which significantly challenges these financial policies stands a chance of being accepted by the government. Safeguarding the low tax and surplus budget policies can also be seen as the government's attempt to comply with ideological and financial limits set by political leaders in Beijing. Since the reintegration of Hong Kong into China in 1997, Hong Kong has been ruled under the Basic Law. Article 5 of the Basic Law stipulates:

'The socialist system and policies shall not be practised in the Hong Kong Special Administrative Region, and the previous capitalist system and way of life shall remain unchanged for 50 years'.

Article 107 of the Basic Law stipulates:

'The Hong Kong Special Administrative Region shall follow the principle of keeping the expenditure within the limits of revenues in drawing up its budget, and strive to achieve a fiscal balance, avoid deficits and keep the budget commensurate with the growth rate of its gross domestic product'.

These quotes, to a certain extent, explain why the Hong Kong government is unwilling to commit itself to provision of extensive welfare measures no matter whether these measures can be used to uphold the adult worker model or the male-breadwinner model. The evidence of the underdevelopment of the CSSA scheme, carers' allowances and spouse tax allowances shown below suggests that the strategy used by the government to reinforce the Chinese tradition to assist people to play the role of the family care provider and to strengthen the male-breadwinner model is far from strong.

The CSSA scheme is a non-contributory benefit measure financed by tax revenues. It has the potential to support full-time family care providers to achieve secure retirement. However, the government has no intention to develop such potential as the benefits given to users are very limited. The monthly basic allowance $(\mathrm{HK} \$ 3,585)$ provided by the CSSA scheme for a single ablebodied adult aged over 60 is lower than the poverty line for one-person household (HK\$4,000) (Census and Statistics Department, 2017). Similarly, carers' allowances in Hong Kong are far from adequate. The amount of carers' allowance for taking care of one person is HK $\$ 2,400$ per month. 
It is even less than the basic allowance provided by the CSSA. Although there are spouse and child tax allowances in Hong Kong, they are not much help especially to people of the lower class. In 2019 , the spouse tax allowance was HK\$264,000 and the child tax allowance was HK\$120,000 for each child. However, a considerable number of people earn less than HK\$11,000 a month and they are not required to pay tax (Chau et al., 2016).

In view of the limitations of the CSSA scheme, carers' allowances, and the tax allowances in providing family care providers with financial support, it is reasonable to argue that the government's approach to the male-breadwinner model is as weak as its approach to the adult worker model. Table 3 provides a brief summary of the Hong Kong government's strategies for responding to the two models.

Table 3 Hong Kong government's strategies for responding to the two models

\begin{tabular}{|c|c|c|}
\hline & Adult worker model & Male-breadwinner model \\
\hline Weak action strategy & $\begin{array}{l}\text { - The government stresses that } \\
\text { women should take an active } \\
\text { part in formal employment } \\
\text { and expects that women can } \\
\text { make contribution to the } \\
\text { MPF for forty years. } \\
\text { - There are only five days of } \\
\text { statutory paid paternity } \\
\text { leave. } \\
\text { - There is no statutory parental } \\
\text { leave. } \\
\text { - The length of the paid } \\
\text { maternity leave is } 10 \text { weeks. } \\
\text { - There are no universal free } \\
\text { childcare services. } \\
\text { - There is a wide gap between } \\
\text { the end of the paid maternity } \\
\text { leave and the age of children } \\
\text { attending the kindergartens: } \\
2 \text { years and } 38 \text { weeks. }\end{array}$ & $\begin{array}{l}\text { - The government stresses } \\
\text { that members of the family } \\
\text { should be key care } \\
\text { providers. } \\
\text { - The basic allowance } \\
\text { provided by the CSSA is } \\
\text { low. } \\
\text { - The amount of the carers' } \\
\text { allowance is even lower } \\
\text { than the basic allowance } \\
\text { provided by the CSSA. } \\
\text { - Most people on low } \\
\text { incomes cannot receive the } \\
\text { support of spouse tax } \\
\text { allowances because they are } \\
\text { not required to pay tax. }\end{array}$ \\
\hline
\end{tabular}

\section{THE STUDY OF YOUNG WOMEN}

Our study on Hong Kong Chinese young women's views on the extent to which the government supports them to save pension incomes through the MPF and their alternative ways of achieving secure retirement was conducted in 2019 in collaboration with a social service centre in Kwai Chung, one of the residential districts in Hong Kong. We recruited Hong Kong Chinese women who were aged 25-30, had been earning incomes higher than the median income of Hong Kong for five years or more, and had been contributing to the MPF. We focus on this target group because they are seen by the Commission on Poverty as people who have the potential to save sufficient amount of pension incomes through the MPF. To recruit participants, roadside stalls were set up in busy locations in Kwai Chung. Those who were interested in the study were invited 
to attend a semi-structured interview at the centre or a place convenient to them. Participants were also encouraged to invite their friends or peers to participate in the study. An information sheet was distributed beforehand and a consent form was signed at the beginning of each interview. Principles of voluntary participation, confidentiality, and anonymity were strictly followed throughout the research process. All interviews were recorded and transcribed. Table 4 provides a brief summary of the characteristics of the participants. 30 women participated in the semistructured interviews to share their experiences of taking part in the MPF. The sample was diverse in terms of marital status, working experience, incomes, and educational background. Pseudonyms are used to ensure confidentiality.

Table 4 Personal characteristics of participants

\begin{tabular}{|c|c|}
\hline Age & 25-30 (median age: 28 ) \\
\hline Occupation & Skilled (7); Professional (11); Management and administration (12) \\
\hline Marital Status & Married (4); Married with child(ren) (4); Single (22) \\
\hline Education Attainment & $\begin{array}{l}\text { Secondary (5); Associate Degree (8); University Degree or Above } \\
\text { (17) }\end{array}$ \\
\hline Monthly Incomes & $\begin{array}{l}\text { below HK\$18,000 (3); HK\$18,001 - HK\$21,000 (13); } \\
\text { HK\$21,001 - HK\$24,000 (7); HK24,001, - 27,000 (4); } \\
\text { HK\$27,001 or above (3) }\end{array}$ \\
\hline Working experience & 5 years $(21) ; 6-7$ years $(5) ; 8$ years or more $(4)$ \\
\hline
\end{tabular}

Given the sample size and purposive sampling, particularly the recruitment of participants from only one district, this study by nature is illustrative rather than extensive. The goal of the present study is to develop a much richer understanding of processes, motivations, beliefs, and attitudes (Rowlingson, 2002). The significance of the interpretation of meanings and actions of actors based on their own subjective frames of reference should not be under-estimated. The research procedure for this study was designed with reference to previous studies (Foster, 2012; Taylor-Gooby, 2005). Several topic areas for the interviews were identified on the basis of the existing literature on the adult worker model, the male-breadwinner model, and the MPF. Participants were invited to freely share their views on the MPF and its possible alternatives as well as their experiences and aspirations related to their family and/or work lives.

Based on Braun's and Clarke's (2006) guidelines, thematic analysis was used to analyze the interview data. We coded all transcripts line-by-line and generated codes in order to identify patterns of meanings in the data. We then sorted the different codes into potential themes by 
carefully considering the relationships between different codes and between different themes. To do so, we constantly looked into both similarities and differences of meanings in individual responses and clusters of individual responses related to the potential themes. We identified the following four themes, which were repeatedly discussed during the interviews. These themes include: 1) Worries about saving pension incomes through the MPF; 2) the government's roles in tackling difficulties faced by women; 3) individual efforts in saving pension incomes; and 4) preferences for participation in the family and/or work economy.

\section{INTERVIEW FINDINGS}

\section{Worries about Saving Pension Incomes through the MPF}

Only two participants expressed no worry about saving sufficient pension incomes through the MPF. The rest of the participants expressed that it was not easy to save sufficient pension incomes through the MPF, even though they had managed to save money through the scheme for over five years. Several reasons for such difficulty were raised by the participants, such as uncertainties of the job market, the poor performance of the organizations responsible for investing their MPF savings, and concerns over health conditions for working for a long period of time. The main reason shared by most of the participants (almost two-third of them) was the care responsibilities they needed to bear in their families. According to the participants, their family commitment was likely to disrupt their career and their chance of contributing to the MPF unremittingly for a long period of time. For example, Sze-wing said:

'I started to work at the age of 23. During the past 7 years, I left the job market for more than one year. The main reason is that my mother's health has been in decline. I need to look after her full time until I am able to find a suitable domestic maid to share my responsibilities. If your mom is sick, you get no choice. You need to stop working and look after her.'

Lok-sum and Wing-yee were planning to form a family with their respective partners in the near future. Both of them said that they were prepared to stop working if they have a child after marriage. Lok-sum said:

'My partner does not earn a lot. If I stop working, we will face economic pressure. However, I will still quit my job if I have a baby. Childcare services in Hong Kong are expensive.'

Wei-lok and Ma-yee had stopped working for two years after having their first baby. Weilok said:

'My mother-in-law has kindly helped me to look after the baby. But she was too old to do all the care work. When my child was one year old, I quitted my job and became a full-time housewife. I think I have made the right decision. It is good to both my baby and my motherin-law.'

These examples demonstrate that many Hong Kong Chinese women still carry huge burden of taking care of children in the family. It could be difficult, if not impossible, for them to comply with the expectations of the MPF scheme and to continuously work for 40 years. It is thus not 
surprising to see the vast majority of participants share worries over the prospect of saving enough pension incomes for retirement.

\section{The Government's Roles in Tackling Difficulties Faced by Women}

More than two third of the participants (24 out of 30) believed that the government had the responsibility for helping women tackle their difficulties in saving pension incomes through the MPF (see Chart 1).

\section{Chart 1 Participants' (30) views on the government's role in helping women save pension incomes}

\section{Participants' Views on Government Support}

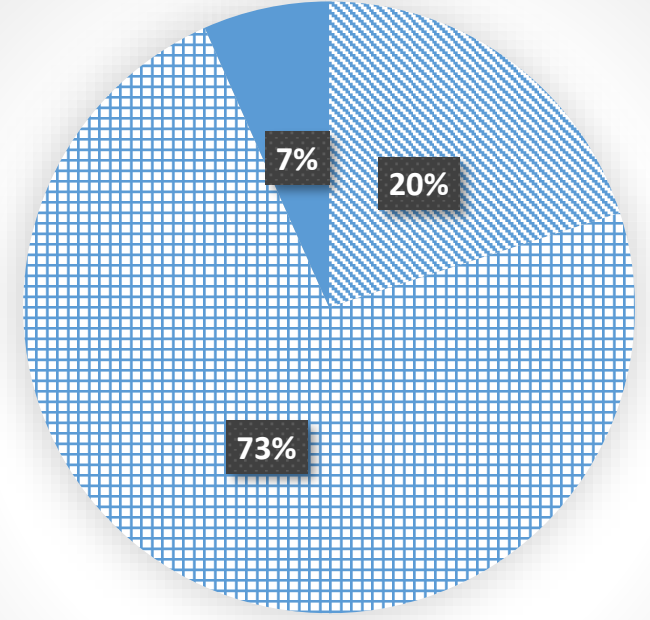

Nad no expectations on the government

\pm Did not think that the government has done enough to help women to save pension incomes

Believed that the government has done its job in helping women to save pension incomes

Mei-ling said: 'I work in Hong Kong and I pay tax. The government has the responsibility to ensure that I can have an acceptable standard of living when I retire.' Lai-mei said: 'Elderly poverty is a serious problem in Hong Kong. To avoid that, the government should help young people like us to save pension incomes.' However, most participants did not think that the government had done well enough to help women save pension incomes through the MPF or any other alternatives. They made several suggestions about how the government may help them tackle their difficulties:

i. creating more favorable conditions for women to develop their career by strengthening public childcare services and providing paid parental leave;

ii. legally allowing women to use their spouses' savings in the MPF account;

iii. subsidizing full-time family care providers to contribute to the MPF;

iv. providing a special pension scheme for full-time care providers; and

v. supporting men to take up more care work by providing paid parental leave and enforcing regulations that can shorten their working hours. 
Mei-wah and Lai-mei were in favor of the suggestion that women' opportunities for developing their career should be enhanced. Mei-wah said:

'I am keen to have my own career. Going to work can enrich your life and help you achieve financial autonomy in the family. Many friends of mine share the same thought. However, their career is often disrupted by the unfair allocation of unpaid work in the family. The government should help women solve this problem. Providing paid parental leave and affordable public care services for children and older people would help.'

Lai-mei also said: 'The paid maternity leave in Hong Kong is too short. If the government can increase it to one year, it can help a number of women with young children to continue their career and save money through the MPF.' On the other hand, Zoe, Wing-shan, and Mei-ki stressed that some women prefer to serve as a full-time care provider in the family and that the welfare of this group of women should be looked after. Zoe said:

'To ensure that those full-time care providers have a reasonable standard of living, the government should set up a special pension scheme for them. If it fails to do this in the near future, it should implement some interim measures, such as contributing to the MPF on behalf of full-time care providers and raising the existing carers' allowances.'

Another participant Wing-shan expressed that saving pension income was not an individual issue but a family issue. She suggested that women should be legally allowed to use the money saved by their spouses in the MPF account. Mei-ki also supported this idea as she believed that all family members, irrespective of the levels of participation in formal employment and incomes, should share financial resources.

Wing-shan, Jiang-yu, Shan-shan, Chen-yeung, Ye-yan, Mei-han shared the view that men should be given more support to provide care in the family. Wing-shan said: 'Women will have more time and greater chance to develop their career if men are given support from the government to share more unpaid work in the family.' This view was supported by Chen-yeung, who believed that the government should encourage more men to share the care responsibilities in the family so as to give women more free time. Similarly, Jiang-yu said: 'Men have the responsibilities for providing care to their family. Moreover, they deserve to be given the opportunity for developing their potential for taking care of other family members. Some men I know enjoy doing unpaid care work.' Mei-han said: 'Gender equality can be promoted by not only equal work opportunities but also equal allocation of unpaid care work in the family between men and women.' Similar view was shared by Ye-yan. She said that 'As more and more women go out to work, men should take up more unpaid care work in the family.' These views highlight that there is an urgent need for the government to address women's concerns over the unfair allocation of unpaid care work in the family and to introduce new policy measures to encourage more men to take up care responsibilities in their families. 


\section{Individual Efforts in Saving Pension Incomes}

Almost all participants believed that they should bear their individual responsibility to save some pension incomes for their retirement. However, most of them did not think that the individual efforts they made could guarantee them a safe retirement. Some attributed this problem to uncertainties of the job market. For example, Mei-wah claimed that it was difficult for employees to have any long-term saving plan as work contracts were increasingly shortened. Both Mei-sau and Wai-shan pointed out that marrying a man and forming a new family would add a lot of uncertainties to the future plan. Mei-sau said:

'Many things could happen in an unpredictable way. For example, if you suddenly have a child, you need to stop working and as a result can no longer contribute to the MPF. I have a friend who planned to work for five years before thinking about marriage and having a child. However, unexpected pregnancy has made her give up her career plan.'

Three participants planned to migrate to other countries. One of them (Lily) said: 'You need to start everything again once you land on another country. I find it quite impossible to make any concrete plan before leaving Hong Kong'.

Despite the uncertainties of the job market and those of family planning, some participants tried to make individual efforts to secure a better retirement life. Working in the government as a civil servant, Ah-sze spent time learning to do small business and making financial investments. She believed that doing small business, despite its risks, could enable her to continue to earn money after retirement. Bo-yi tried hard to find a permanent job. Ka-ka reported that she had been making careful plans with her boyfriend about their future, especially plans related to migration and childcare.

\section{Preferences for Participation in the Family and/or Work Economy}

The majority (18 out of 30) of the participants preferred to develop their own career (see Chart 2). 


\section{Chart 2 Preferences for participation in the family and/or work economy}

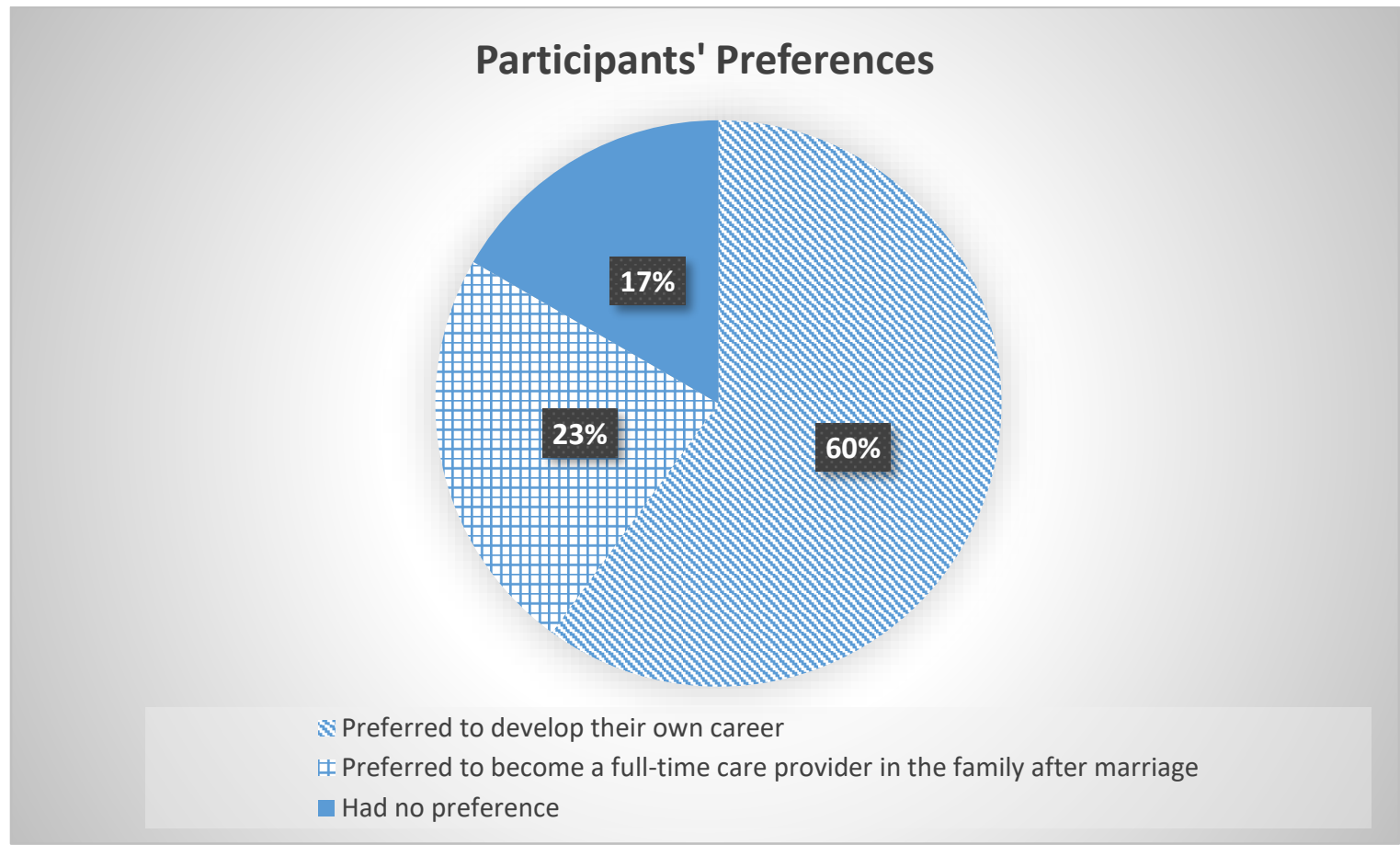

Wing-shan reported, 'I prefer to have my own career. This helps me to earn money and respect.' This view was echoed by Mei-han, who said, 'getting a stable job is the first step to gain respect and some degree of gender equality.' However, half of these 18 participants reported that they were prepared to leave the paid labor market for at least a short period of time if they needed to take care of their family members and/or if they have their babies.

Seven participants preferred to become a full-time care provider in the family one day after marriage. Zoe was one of them. She said, 'Every family needs a person to take up the major caring tasks. I don't mind playing that role. That can prevent any major crises from happening.' Mei-ki shared a similar view, 'I prefer to play the role of the full-time care provider. It is because I think that every family needs a person to take this role. And I think I will enjoy looking after my family.'

Five participants reported having no preference. Wei-sum explained that she was too young to have any concrete ideas about issues concerning career development and the family:

'I am 27 years old. It is a bit too young to make a final decision as to whether to devote my life to career or to the family as a full-time housewife. Even if I say I have made a final decision on these issues, I may change my mind later. I think all the important decisions I will make in the near future are at most semi-final ones.'

Wing-see and Ah-bo said that it was not very meaningful to talk about their preferences because the interests of their family members took precedence over their own. Wing-see said, 
'Perhaps it is due to my personality. I always let my parents choose first. If they need me to look after them, I will give up my career. If they can look after themselves, I think I will work for a few more years before coming up with any long-term plans.'

\section{DISCUSSION}

The discussion of the four themes enhances our understanding of not only women's views on the MPF but also those on the government's approaches to the adult worker model and the malebreadwinner model. This section highlights three lessons learnt from the findings - the importance of the government in ensuring the adequacy of individual pensions, the double burden faced by women, and the significance of revising the government's approaches to the adult worker model and the male-breadwinner model.

\section{The importance of the government in ensuring the adequacy of individual pensions}

A number of participants stressed that they had to take individual responsibility to save pension incomes for their retirement. Some participants (such as Ah-sze and Bo-yi) made individual efforts to improve their chance of achieving secure retirement (such as by learning to do business and looking for a permanent contract). However, most participants were not optimistic that the efforts they made were sufficient to guarantee safe retirement. The pessimistic views of the participants on the effectiveness of their individual efforts in ensuring the adequacy of their pension incomes are understandable. The interview findings show that all participants, except two of them, had difficulties in saving sufficient pension incomes for retirement, and at the same time, in participating in the family in the ways they preferred. This suggests that the government should play an important role in helping women to accumulate sufficient pension incomes for the later stage of their lives. The need for government action is shown by the belief shared among most participants that the government had some responsibilities to help them to save pension incomes.

\section{Double burden}

The difficulties faced by participants in saving pension incomes through the MPF reflect that most of them faced double burden issue - they were expected to take part in formal employment and bear most of the care responsibilities in the family at the same time. This issue has been discussed by previous studies (Bambra, 2007; Lohmann \& Zagel, 2016; Saxonberg, 2013). In the Hong Kong context, the design of the MPF implies that women are expected to take part in formal employment and contribute to the income-related retirement saving scheme for 40 years. However, the findings suggest that women still suffer from the burden of family commitment. It is thus difficult for most participants to provide care in the family and at the same time save sufficient pension incomes for retirement.

\section{Revising the government's approaches to the two models}

In order to ensure that women can have sufficient pension incomes to maintain a reasonable standard of living in the later stage of their lives, it is necessary for the government to revise its approach to both the adult worker model and the male breadwinner model. This point is reflected 
in the suggestions made by participants for policy measures that the government should adopt. Some suggestions (such as strengthening public childcare services and providing paid parental leave) can lead to better conditions for women to participate in formal employment. Other suggestions (such as legally allowing women to use the savings in their respective spouses' MPF accounts, subsidizing full-time family care providers to contribute to the MPF, and providing a special pension scheme for full-time care providers) can increase family care providers' chance of securing sufficient resources for retirement. These suggestions reflect that not all participants wanted to organize their lives with reference to the adult worker model; some preferred to play the role of the full-time care provider in the family. In order to meet the participants' diverse preferences for the organization of the adult life, the government should put all the suggestions into practice. This also means that it should give up its weak action strategy for supporting the adult worker model and that for supporting the male-breadwinner model.

\section{CONCLUSION}

This article is intended to meet two objectives - to discuss the strategies used by the Hong Kong government to respond to the adult worker model and the male-breadwinner model; and to explore the views of women on the desirability of these strategies for enhancing their freedom to choose to take part in formal employment and/or to participate in the family as the main care provider. Based on the discussion of the policy measures for supporting people to save pension incomes through the MPF and other policy measures for helping family care providers to achieve secure retirement, we argue that the government adopts the weak action strategy to respond to both the adult worker model and the male breadwinner model. As shown by the findings, this strategy is ineffective in guaranteeing women safe retirement and enhancing their freedom to choose to take part in formal employment and/or to participate in the family as the main care provider. Therefore, in order to enhance the welfare of women, what the government should do is not to strengthen the adult worker model at the expense of the male breadwinner model or vice versa; it should adopt the strong action strategy to support both the adult worker model and male-breadwinner model so that it can meet the diverse needs of women. However, there is no guarantee that the government is going to make this change. Adopting a more proactive approach to the two models requires the government to reduce its support of neo-liberal ideologies, revise the surplus budget and low tax policies, and ignore the financial limits set by the Basic Law. There is no sign that the government is willing to make these changes. The ways the government rules Hong Kong have long been influenced by incrementalism and short-termism. It is not unusual that the government chooses to simply give people cash (through various means) instead of using the available financial resources to make institutional changes to the current system. This, to a certain extent, suggests that the government's willingness to make significant revisions to its approaches to the adult worker model and the male-breadwinner model should not be over-estimated.

For future research, it is worth studying the lived experiences of women in other age groups, such as women in their middle age. They may provide further insights into the difficulties faced by different groups of women in saving pension incomes and the extent to which the government's response to the adult worker model and the male-breadwinner model meets people's needs. With more data gained from future studies, we will have a better chance of making the support offered by welfare regimes sensitive to women's diverse preferences. 


\section{NOTES}

1. Different analysts used different terms to describe the model that promotes women's and men's equal engagement in the labor market. For example, Ciccia and Bleijenbergh (2014) termed this model as 'universal breadwinner model'. Daly (2011), Lewis (2001), and Annesley (2007) termed this model as 'adult worker model'.

2. The 'Three Types of Obedience' refer to the obedience of a girl to her father, that of a married woman to her husband after marriage, and that of a widow to her son; and the 'Four Virtues' refer to performing appropriate behaviors in conformance to the moral code, being careful in her speech, keeping the appearance modest, and being diligent in the management of domestic duties (Steele, 1966; Chau \& Yu, 2013).

3. Workers before age 65 are not allowed to claim back the accumulated savings in the MPF account even after they stop working and stay at home with their children. Those who are out of employment are not legally required to contribute to the MPF. If women want to unremittingly contribute to the MPF after giving birth to a baby, they may need to rely on childcare services so that they can reduce the burden of childcare and continue to work. It is understandable that some women may choose not to go back to work after childbirth if the cost of childcare services is much more than the money they can save through the MPF.

4. The Old Age Allowance Scheme provides a monthly allowance to Hong Kong residents who have severe disabilities or who are aged 65 or above with special needs arising from disability or old age.

5. Parents are not legally obliged to send their children to attend kindergartens, but almost all children aged between 3 and 6 study in the kindergartens in Hong Kong (The University of Hong Kong, 2018). Although the government provides 12 -year free primary and secondary education, all kindergartens in Hong Kong are privately owned and operated (Lee \& Bagley, 2017). The monthly private school tuition is about $\mathrm{HK} \$ 8,500$ on average. This fee amounts to approximately $57 \%$ of the average monthly salary of a man, $70 \%$ of the average monthly salary of a woman, and $31 \%$ of the sum of the average monthly salaries of a man and a woman. This implies that if a heterosexual couple earning average salary wants to send their child to a private school, both adults are likely to work full-time to afford the tuition. Not all couples with average incomes want to both work full-time and/or spend over 30\% of what they earn on their children's education. Research also shows that school choice differs considerably between families with different socio-economic status (Lee \& Bagley, 2017).

6. The exchange rate between US Dollars and Hong Kong dollars is 7:1.

7. The Employees Retraining Board provides about 700 training courses every year. The Labor Department also offers free employment services to job seekers. These services include the provision of information about employment and training and personalized employment advisory services.

8. The labor force participation rate by age group and sex in 2018 (Census and Statistics Department, 2019b):

Age 15-19 (female: 12\%; male:10.4); age 20-24 (female: 60.4\%; male:60.2\%); age 25-29 (female: 86.6\%; male: 92.9\%); age 30-34 (female: 82\%; male:96.4\%); age 35-39 (female: 76.9\%; male: $96.4 \%$ ); age $40-44$ (female: $75.5 \%$ and male: $96.7 \%$ ); age $45-49$ (female: $72.6 \%$ and male: 94.6\%); age 50-54 (female: 68.7\%; male: 91.8\%); age 55-59 (female: 54.4\% and male: $82.6 \%$ ); age 60-64: (female: $33.6 \%$ and male: $61.4 \%$ ); age 65 and above (female: $6.1 \%$ and male: $18.2 \%$ ); overall (female: $55.1 \%$ and male: $68.5 \%$ ). 
9. Women's labor force participation rate by educational attainment in 2018 (Census and Statistics Department, 2019b):

No schooling/pre-primary (7.7\%), primary (27.9\%), lower secondary (47\%), upper secondary (62.8\%), post-secondary non-degree (66.9\%), post-secondary degree (73.4\%), overall (55.1\%).

\section{ACKNOWLEDGEMENTS}

This paper is partly supported by the General Research Fund under the Hong Kong Research Grants Council (grant number 12604517); and part of the work has received funding from the Marie Skłodowska-Curie Actions under the European Union's Horizon 2020 research and innovation programme under grant agreement No 708305.

\section{REFERENCES}

Annesley, C. (2007). Women's political agency and welfare reform: Engendering the adult worker model. Parliamentary Affairs, 60(3), 452-466.

Bambra, C. (2007). Defamilisation and welfare state regimes: A cluster analysis. International Journal of Social Welfare, 16(4), 326-338.

Braun, V., \& Clarke, V. (2006). Using thematic analysis in Psychology. Qualitative Research in Psychology, 3(2), 77-101.

Census and Statistics Department (2015), Thematic Household Survey Report No. 56, Hong Kong: Hong Kong Special Administrative Region.

Census and Statistics Department (2017). Hong Kong poverty situation report 2016. Hong Kong: Census and Statistics Department. Retrieved from https://www.povertyrelief.gov.hk/eng/pdf/Hong_Kong_Poverty_Situation_Report_2016(201 7.11.17).pdf

Census and Statistics Department (2019a). Quarterly report of wage and payroll statistics. Hong Kong: Census and Statistics Department. Retrieved from https://www.censtatd.gov.hk/hkstat/sub/sp210.jsp?productCode=B1050009

Census and Statistics Department (2019b). Women and Men in Hong Kong Key Statistics. Hong Kong: Census and Statistics Department. Retrieved from https://www.statistics.gov.hk/pub/B11303032019AN19B0100.pdf

Ciccia, R., \& Bleijenbergh, I. (2014). After the male breadwinner model? Childcare services and the Division of Labor in European Countries. Social Politics, 21(1), 50-79.

Chau, R. C. M., \& Yu, S. W. K. (2013). Defamilisation of twenty-two countries: Its implications for the study of East Asian welfare regime. Society and Social Policy, 12(3), 355-367.

Chau, R. C. M., Foster, L., \& Yu, S. W. K. (2016). Defamilisation and familisation measures: Can they reduce the adverse effects of pro-market pension reforms on women in Hong Kong and the UK? Critical Social Policy, 36(2), 205-224.

Crompton, R. (ed) (1999). Restructuring gender relations and employment: The decline of the male breadwinner. Oxford: Oxford University Press. 
Commission on Poverty (2015). Retirement protection forging ahead: Consultation document. Hong Kong: Government Logistics Department.

Daly, M. (2011). What adult worker model? A critical look at recent social policy reform in Europe from a gender and family perspective. Social Politics, 18(1), 1-23.

Dyer, S, McDowell, L and Batnitzky, A. (2011), Migrant work, precarious work-life balance: what the experiences of migrant workers in the service sector in Greater London tell us about the adult worker model, Gender, Place and Culture, .

Foster, L. (2010). Towards a new political economy of pensions? The implications for women. Critical Social Policy, 30(1), 27-47.

Foster, L. (2012). "I might not liv that long!" A study of young women's pension planning in the United Kingdom. Social Policy and Administration, 46(7), 705-726.

Hong Kong SAR (HKSAR) Government (2014). Population policy: Thoughts for Hong Kong. Hong Kong: Central Government Offices.

Jones, C. (1993). New perspectives in the welfare state in Europe. London: Routledge.

Karim, S. A, Eikemo, T. A., \& Bambra, C. (2010). Welfare state regimes and population health: Integrating the East Asian welfare states. Health Policy, 94(1), 45-53.

Kovacs, R. (2013). Developmental states and gender-equity: Is the achievement of gender-equity compatible with the logic of the developmental state? E-International Relations. Retrieved from http://www.e-ir.info/2013/04/13/developmental-states-and-gender-equity/

Labour and Welfare Bureau (2019). Replies to initial written questions raised by Finance Committee Members in examining the Estimates of Expenditure 2019-20 (welfare and women). Retrieved from http://www.legco.gov.hk/yr18-19/english/fc/fc/w_q/lwb-ww-e.pdf

Lam, C. (2017). Policy address: We connect for hope and happiness. Retrieved from https://www.Policyaddress.gov.hk/2017/eng/pdf/PA2017.pdf

Lee, A. N., \& Bagley, C. (2017). School choice with education vouchers: An empirical case study from Hong Kong. International Studies in Sociology of Education, 26(1), 3-18.

Legislative Council Secretariat (2019). Opportunities and challenges facing maternal workforce in Hong Kong, Research Brief Issue No. 22018 - 2019 (July 2019). Retrieved from https://www.legco.gov.hk/research-publications/english/1819rb02-opportunities-andchallenges-facing-maternal-workforce-in-hong-kong-20190716-e.pdf

Leung, C. Y. (2014). The 2014 policy address. Retrieved from https://www.policyaddress.gov.hk/2014/eng/pdf/PA2014.pdf

Leung, L. C. (2018). Gender matters: Rethinking the childcare model in Hong Kong. Children \& Society, 32(5), 393-404.

Leung, L. C., \& Chan, K. W. (2012). A family-friendly policy for Hong Kong: Lessons from three international experiences. The International Journal of Sociology and Social Policy, 32(1/2), 82-95.

Lewis, J. (2001). The Decline of the Male Breadwinner Model: Implications for Work and Care. Social Politics: International Studies in Gender, State \& Society, 8(2), 152-169.

Lewis, J., \& Giullari, S. (2005). The adult worker model family, gender equality and care: The search for new policy principles and the possibilities and problems of a capabilities approach. Economy and Society, 34(1), 76-104.

Lohmann, H., \& Zagel, H. (2016). Family policy in comparative perspective: The concepts and measurement of familization and defamilization. Journal of European Social Policy, 26(1), 48-65. 
National Statistics, Republic of China (Taiwan) (2018). Gender at a glance 2018 in R. O.C. (Taiwan). Retrieved

from https://eng.stat.gov.tw/public/data/dgbas03/bs2/gender/eb/2018/2018E.pdf

Price, D. (2007). Closing the gender gap in retirement income: What difference will recent UK pension reforms make? Journal of Social Policy, 36(4), 1-23.

Rowlingson, K. (2002). Private pension planning: the rhetoric of responsibility, the reality of insecurity. Journal of Social Policy, 31(4), 623-642.

Saxonberg, S. (2013). From Defamilisation to Degenderization: Toward a New Welfare Typology. Social Policy and Administration, 47(1), 26-49.

Shi, S. J., \& Mok, K. H. (2012). Pension privatisation in greater China: Institutional patterns and policy outcomes. International Journal of Social Welfare, 21(1), 30-45.

Social Welfare Advisory Committee (2010). Long-term social welfare planning in Hong Kong (Consultation Paper). Retrieved from https://www.gov.hk/en/theme/bf/pdf/SWAC_Consultation_Paper.pdf

Steele, J. G. (1966). The I-li (Book of etiquette and ceremonial). Taipei, Taiwan: Chengwen Publishing Company.

Taylor-Gooby, P. (2005). Uncertainty, trust and pensions: the case of the current UK reforms. Social Policy and Administration, 39(3), 217-232.

Teo, P., \& Yeoh, B. (1999). Interweaving the public and the private: women's responses to population policy shifts in Singapore. International Journal of Population Geography, 5(2), 79-96.

The University of Hong Kong, The Hong Kong Jockey Club Centre for Suicide Research and Prevention (2018). The final report of the consultancy study on the long-term development of child care services. Hong Kong: The University of Hong Kong.

Tong, Y., \& Chiu, S. W. K. (2017). Women's labor force participation in Hong Kong: 19912011. Chinese Sociological Review, 49(1), 35-64.

Trappe, H., Pollmann-Schult, M. and Schmitt, C. (2015). The Rise and Decline of the Male Breadwinner Model: Institutional Underpinnings and Future Expectations. European Sociological Review, 31(2), 230-242.

Walker, A., \& Wong, C. K. (2005). Introduction: East Asian welfare regimes. In A. Walker \& C. K. Wong (Eds.), East Asian welfare regimes in transition (pp. 3-20). Hong Kong: The Policy Press.

Wong, T., \& Yeoh, B. (2003). fertility and the family: An overview of pro-natalist population policies in Singapore. Asia MetaCentre Research Paper No. 12, Singapore: National University of Singapore.

Xia, L. L. L., \& Ma, J. L.C. (2019). Childcare policies and services in Hong Kong after the handover: Beyond a feminist critique. Asian Social Work and Policy Review, Published online. Retrieved from https://doi.org/10.1111/aswp.12182

Yeh, C-Y., Cheng, H., \& Shi, S-J. (2018). Public-private pension mixes in East Asia: institutional diversity and policy implications for old-age security. Ageing and Society, 1-22. https://doi.org/10.1017/S0144686X18001137

Yu, W. K., \& Chau, R. C. M. (2019). Hong Kong: Ruling principles of the government and responses of social work education and practice. In I. Shaw \& R. Ow (Eds.), Asian social work (pp. 71-85). Routledge.

Yu, S. W. K., Chau, R. C. M., Boxall, K., \& W. C. Y. Chung (2014). Looking to the east and the west: The double-attachment strategy used by the Hong Kong government to develop welfare 
to work measures for lone parents. Journal of International and Comparative Social Policy, 30(2), 93-106.

Yu, S. W. K., Foster, L., Chau, R. C. M., \& Lee, A. M. (2017). An investigation of defamilization/familization measures to assist women to save pension income and strengthen the adult worker model-The case of Hong Kong. Asian Social Work and Policy Review, 11(3), 234-243.

Yu, S. W. K., Chau, R. C. M., \& Kühner, S. (2019). Defamilisation and familisation risks, adult worker models, and pro-employment/decommodification measures for women: The case of Hong Kong. Journal of International and Comparative Social Policy, 35(2), 194-210. 